\title{
CANDI GUNUNG GANGSIR AND THE CHARACTER OF THE EARLY EAST JAVANESE ARCHITECTURE
}

\section{Peter R. Hoffmanns}

Keywords: temple; architecture; hindu; buddha; east java

\section{How to Cite:}

Hoffmanns, P. R. (1987). CANDI GUNUNG GANGSIR AND THE CHARACTER OF THE EARLY EAST JAVANESE ARCHITECTURE. Berkala Arkeologi, 8(1), 4670. https:/ / doi.org/10.30883/jba.v8i1.485

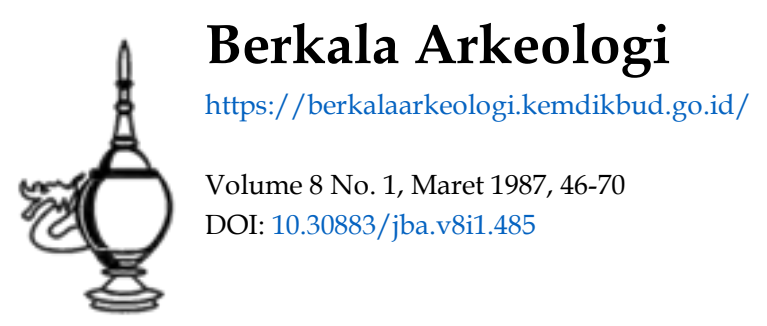




\title{
CANDI GUNUNG GANGSIR AND THE CHARACTER OF THE EARLY EAST JAVANESE ARCHITECTURE
}

\author{
By: Peter R. Hoffmanns*
}

\section{Introduction}

In this contribution I would like to draw some attention to a period which is widely considered to be a black hole or a white spot, in any case "a blank in Indonesian archaeology" (Soekmono 1969:3). It needs no explanation that I am alluding to the period of the tenth until the thirteenth century A.D.

Within this period, especially at the beginning of the tenth century, the centre of power shifted from southern Central Java to the important river areas of the Solo, Mas and, particularly, Brantas rivers in East Java. During this period of three centuries some major and minor important East Javanese powers arose which have left a wealth of epigraphical and literary material.

However, the sacrity of well preserved archaeological, especially architectural remains from this period is striking. This is all the more regrettable because every scholar in this field of research is fully aware that the answer to the frequently posed question, concerning the change in style of Old Javanese architecture might well be founf in this period.

Concerning this style, some facts first. The architecture from the period prior to the tenth century is mainly and abundantly found in southern Central Java. This Central Javanese tradition is originally inspired by Indiar traditions, but in execution it is characterized by clearly discernable Indonesian, not to say Javanese peculiarities.

- Dept. of Languages and Cultures of Southeast Asia and Oceania, State University of Leiden, the Netherlands. 
The vast majority of the architecture from the period after the middle of the 13th century can be encountered in the quadrangle formed by the cities Surabaya. Kediri, Blitar and Malang. This building art is of a different signature in comparison to the Central Javanese architecture. This means to say that East Javanese art, considered from the viewpoint of conception, sphere and form contains more innate elements in comparison to the Central Javanese art.

Let us turn back to the change of style in Old Javanese art. The important question is: Can one speak of an unbroken and clearly traceable development from the Central Javanese architecture (especially the late Central Javanese architecture, dating from the 9th century A.D.) to the East Javanese architecture from the middle of the 13th century onwards (the late East Javanese architecture)? Or, is it a question of a different line of development?

The opinions concerning the relation between Central and East Javanese arts

Regarding the above mentioned questions, three opinions have been formulated in the past. In 1904 already Brandes proposed a certain theory which has been worked out by Krom during the early twenties and which has been supported by Soekmono in the sixties. According to Krom (1923 I:63 and II:1,460), the later East Javanese art gradually developed from the Central Javanese art. Bouth scholars were very well aware of the fact that both Central and late East Javanese art had their own distinct characteristics. However, Krom considered these distinctions to be caused by the lapse of more than three centuries between the late Central and East Javanese arts. He supposed that during this period some development must have taken place. A development which perhaps is hidden from our eyes because almost no archaeological evidence has survived from this period.

This scarcity and fragmentation of archaeological evidence led Soekmono (1969:3) to the following formulation: "a real gap does 
not exist". According to him this gap only showed the incompleteness of the picture. Brandes and Krom based their opinion on one factor: the existence of three specific monuments, candi Loro Jonggrang, candi Gunung Gangsir and the gates of the Belahari complex. According to both scholars, candi Loro Jonggrang, a Central Javanese monuments, showed the influence of the East Javanese style. Candi Gunung Gangsir and the Belahan gates, both from East Java and both built in brick, so commonly used in the later East Javanese period, showed a mainly Central Javanese style. Because of this both Brandes (1904:415) and Krom (1923 I:63) considered these monuments as links between the Central and East Javanese art styles. Krom suggested a continuity between both styles which led him to the supposition of the unity of Old Javanese art.

One of Indonesia's leading archaeologists, Professor Soekmono showed himself to be a follower of Krom's theory regarding the unity of Old Javanese art (Soekmono 1969:3). His presupposition merely implied that one should look for more archaeological data from this period of emptiness and that, consequently, the line of development will appear by itself. Soekmono was able to succeed in one case. Since 1957 he excavated at Gurah, some ' $k m s$ to E East of Kediri. There he encountered the remains of a monument which possessed certain elements, pointing to Central Javanese influence, such as the presence of an ogive in parts of the profile, the presence of a makara, placed at the end of a staircase wing and the distribution of the complex, reminiscent of candi Loro Jonggrang (Soekmono 1969: 5-9, 14). On the other hand statues appeared which showed similarities with the Singosari sculptural style. A dating between the Central Javanese period (the 9th century in particular) and the Singosari period (13th century) seemed sbvious. On top of that an inscription was found, the script of w'ich could be compared with that of 11th and 12th century inscriptions (Soekmono 1969:16). In consideration of these indications, it was Soekmono's conclusion that candi Gurah belonged to the Kadiri period (1049-1222). He suggested that the monument might be called a link between the Central and East Javanese arts, dating from a period "that is neither Central Javanese nor East Javanese" (Soekmono 1969:16). 
Regarding the dating of candi Gurah I would like to add a few remarks. Besides the presence of an ogive (which, by the way, does not point to Central Javanese influence only, as Soekmono suggested) it is very important to mention the presence of the well known Central Javanese combination of ogive/reset, tripartite moulding/ semi-circular moulding (cf.p.54) The ogive at Gurah, however, is flatter than the Central Javanese ones and its contour is straighter in comparison to the "S" shaped curve of the Central Javanese ogive (see PI. 1). The semi-circular moulding too is flatter and its end is sharper in/comparison to its higher, true semi-circular counterpart from Central java. Such a profile combination, as present at candi Gurah, can also be found in the profile of the 10th century monuments at Belahan. This might indicate a date closer to Belahan, perhaps somewhat later, because prior to Belahan we only encounter the true Central Javanese version of this profile combination.

I would like to add the suggestion of Professor De Casparis with relation to the above mentioned inscription from candi Gurah. According to De Casparis the script is closely related to the inscriptions of Airlangga who lived in the first half of the 11th century. Taking Soekmono's evidence together with these remarks into consideration, we might even surmise at date prior to or in the very beginning of the Kadiri period, somewhere in the first half of the 11th century.

After having discussed the first of the three opinions concerning the relation between the Central and East Javanese art styles, I would like to continue with the second opinion, formulated by Stutterheim, one Krom's most promising student. This opinion was further elaborated in more detail by Bosch. Stutterheim (1923) stressed the separation between Central and East Javanese art. According to him, this separation did not originate merely because of the existence of very clear art historical and architectural differences, but particularly as the result of a change in conceptions and ideas behind the different art forms. Nevertheless, Stutterheim agreed with Krom with regard to the gates of Belahan. These gates seem to obscure the sharply drawn line between Central and East Javanese arts. 
They might have served as a link between both art forms. He did not mention candi Gunung Gangsir in this respect. but hinted at it by way of mentioning "other links" (1923: 334) besides Belahan and by quoting Krom who mentioned candi Gunung Gangsir as such (1923:327). Nevertheless, Stutterheim was of the opinion that the change $\mathrm{i}$ art forms had taken place suddenly and that the transformation was striking. With respect to this view, he alluded to the bathing place of Jolotundo, which is located on the western slope of the Gunung Penanggungan and generally dated in the year 977 A.D. According to Stutterheim this monument showed drastic and essential differences, particularly with the reliefs (Stutterheim 1927: 179).

Bosch elaborated on this point of view with respect to Jolotundo. After a careful study of the architecture and the ornamentation, he stated that the art of Jolotundo showed a radical break with the classical tradition of Central Java (Bosch 1965:226-7). According to Bosch this was proven by the fact that many Central Javanese motifs and/or elements were no longer present at Jolotundo. More. over, certain stylistic elements, also applied in Central javanese art, had changed beyond recognition. He considered the contrast extremely striking, having observed the short lapse between the latest examples of Central Javanese art and Jolotundo in particular. Therefore Bosch (1965:228) suggested that Jolotundo was a deliberate attempt to break with the styles prevailing in the foregoing or even current period. He tentatively proposed that Jolotundo might be a continuation of a previous style, the existence of which was obscured because it was hidded behind the remaining stone dominated court architecture (Boch 1965:229). The intricate nature and-delicate details of the reliefs also pointed to a technique of carving, not used in sculpturing stone but one which was practiced in the more plastic art of wood and fired clay. Bosch (1965:230) thereupon mentioned candi Gunung Gangsir because this monument, according to Bosch originating from the same period as Jolotundo, was decorated with terracotta ornamentation. In conclusion, Bosch observed that archaeological evidence like Jolotundo clearly pointed to East Javanese art. At the same time the artistic road to Central Java seemed to 
be blocked. Therefore, according to Bosch, the theory of continuity or unity, as expressed by Krom, needed to be corrected. According to Bosch (1965:231), this theory "is only maintainable on condition that its starting point should not be sought in Central Java (...) but is transferred to the east and to the point in time when, with the foundation of Jolotundo, quite a new style of art emerged from an unrecorded past". This condition seems to be the affirmative answer to a question which was already raised by Galestin in 1936. After a discussion of some architectural details depicted on the reliefs of Jolotundo, he posed the question whether the art of Jolotundo did actually descend from an older East Javanese art which was, even more than the one at Jolotundo, related to Central Javanese art, but of which the remains no longer existed (Galestin 1936:214).

In conclusion we might say that Stutterheim and Bosch both supported the view that the East Javanese art differed so totally from the Central Javanese art that a relation between the two is impossible to make. Bosch added more value to the idea that the true East Javanese art could have been developed from an earlier East Javanese art which perhaps was partly executed in baked clay. In this respect he pointed to the terracotta ornamentation of candi Gunung Gangsir.

I would like to conclude this discussion of current opinions, concernin 3 the relation between the Central and East javanese arts by mentioning a third point of view which was supported by the Indonesian historian Pitono.

In 1971 he wrote an article which, so far as I can see now (September 1986) can be considered as the latest contribution to the solution of the problem concerning the relationship between Central and East Javanese art. In this article Pitono discussed the development of temple architecture in East Java. In this respect he paid attention to the theories of both Krom and Stutterheim. Without giving any arguments Pitono (1971: 70) declared himself a supporter of Stutterheim's views. This seems to be strange because Pitono (1971: 71) considered the period of the tenth to the twelfth century in East Java to be a continuation of the Central Javanese period, 
whereas Stutterheim considered Jolotundo (977 A.D.) in particular as one of the first hallmarks of the new eastern Javanese art. Pitono considered the 12th century of the Kadiri period (1049-1222) to be a gap in the development of the cultural history in East Java, especially with regard to structural art. However, this gap might be closed, according to Pitono, by monuments like candi Gurah. This monument might be date from the 11th century already, as I have suggested earlier (see p.48). After the gap during 12th century there appears a new building art in the 13th century which forms the starting point of the late East Javanese architecture, according to Pitono (1971: 72). In spite of the gap during the 12th century, Pitono still supported the view that the architecture from the period of the 10th until and including the 12th century was a continuation of the Central Javanese building art. In this respect he mentioned the gates at Belahan which, according to Pitono, in spite of their date in the 10th century, still show

Only after the completion of this article I got hold of a copy of an article by J. Dumarcay published in Amerta (Berkala Arkeologi), 9, 1984 (p. 7-13): "Gubahan Arsitektur di Jawa Timur". According to this wellknown French architect, the continuity between the Central and East Javanese art. especially architecture has to be acknowledged As an example, he mentions candi Badut as a monument which was built at the end of the 8th century, but which received several architectural addition in the 9th and the 13th century. Thus, from the 8th till the 13th century this monument was continuously in use (Dumarçay 1984: 7-8). 
a Central Javanese architectural style. Together with these gates $\mathrm{Pi}$ tono (1971:72, note 19) mentioned candi Gunung Gangsir, although this monument, in his view, already showed a marked change in architectural style. I will return to this remark in the discussion of candi Gunung Gangsir.

When we consider the opinions so far mentioned, it seems that a number of four brick monuments played an important role in the East Javanese period of the 10th until the 13th century. These are the monuments at Belahan, the Bathing Place of Jolotundo, candi Gurah and candi Gunung Gangsir. We have to pay attention to candi Gunung Gangsir in particular, because out of these four it is the only monument which had not been subject to further investigation until 1982. This is in spite of the fact that in 1903 Brandes had already stressed the importance of candi Gunung Gangsir in connection with the supposed continuity between the Central and East Javanese arts.

\section{Candi Gunung Gangsir}

Candi Gunung Gangsir is located in the dukuh Kebon Candi, desa Gunung Gangsir, kecamatan Beji, kabupaten Pasuruan. The name of the temple is a reminiscence to a myth, still known to some old inhabitants of the desa and via an informant it was told to us. In earlier days the monument was enclosed by mountains (Gunung in Javanese and Indonesian) and carefully guarded, because it contained treasures. Once upon a time there was a man who had the intention to steal these treasures and in order to carry out his pland, he dug, like a gangsir, a sort of cricket, a tunnel underneath the mountains in the direction of the monument. In this way he succeeded in robbing the treasures. The Indonesian language still contains the form menggangsir (Jav : nggangsir), derived from gangsir. which means "to dig a hole, to dig underneath (especially in order to steal)" 
The brick monument has four floors: two base floors, a true temple body and a roof. The ground-plan of the base floors is square with a projection on the east side. against which a staircase is constructed. The ground-plan of the temple body and the roof is also square, but at these levels on all four sides the walls possess a slightly protruding projection. The temple is in a ruinous state Almost all corners of the different floors are damaged and also the horizontal parts, where one floor meets the other, are in quite poor condition. Moreover, the top part of the roof has disappeared. Because of these damages the monument looks somewhat like a pyramid with a stump top.

The earlier mentioned Pitono probably considered this ruined form as the original one (Pitono 1961). Because of this misinterpretation he spoke of a new architectural form in East Java, which looked like the pre-Hinduistic pyramidal style, well known from the 14 th century and later. On the other hand he ascribed the monument to the period in which the shift from Central to East Java took place, the 10th century. By careful observation of the monu. ment one is able to reconstruct the original form of candi Gunung Gangsir, and this form clearly deviates from the one which is given by Pitono.

Because of the fact that I only carried out an architectural study of candi Gunung Gangsir, the results of which have been laid down in a doctoraal thesis (1984). I will restrict myself to a discussion of five architectural elements which. because of their nature and character, can be compared to those of other Old Javanese monuments. This comparison yielded several similarities with certain Old Javanese monuments. Typological similarities can give indications regarding the date of a monument. It has to be remembered, however. that a typological comparison is just one aspect which can be used in the dating of a monument.

It is clear that a careful study of a monument includes not only a study of its architecture and ornamentation, but also an investigation into its back ground with regard to its sacral and secular function 
Its religious background can be studied e.g. from the style applied in the sculptures, when present, in the topics of the reliefs or in the shape and the lay-out of the monument.

Concerning both its sacrai as well as its secular character, the history which "surrounds" the monument has to be studied. This can be carried out by means of a research in the written literature and the inscriptions of the period, in which the monument is thought to be built.

It is also important to consider the topo- and geographical location of the monument in order to compare this information with, again, the history of the area in which the monument is constructed. Lastly, an analysis of the building material applied in the construction of the monument, has to be included. All these elements together built up to a more complete picture of the monument with regard to its date. In view of the afore mentioned remarks I would like to stress again that, in the limited range of my doctoral thesis, I only studied several elements of the architecture of Candi Gunung Gangsir, on which I based some tentative conclusions concerning the date of the monument.

The first architectural element is the vertical profile of the two base floors (Pls. 2,3). At candi Gunung Gangsir its order shows many similarities with that of the late Central Javanese monuments of candi Loro Jonggrang, in particular with the sequence, present at the two Court Temples within this famous complex. The profile of both candi Gunung Gangsir and candi Loro Jonggrang is quite extensive. At both monuments every floor contains a decorated die (the middle piece or body), enclosed by several base mouldings below and supporting mouldings plus a cornice above. Some of them are ornamented. At both monuments the base mouldings of the first base floor include among others the classical Central Javanese combination, which consists of (from bottom to top) a high ogive in the form of a slightly stretched "S" shape, a small, reset, tripartite moulding and a high or thick semi-circular moulding. On the other hand, candi Gunung Gangsir possesses ornamental mouldings 
immediately underneath and above the die of the base floors. These mouldings, located at these specific places, have not been met with at candi Loro Jonggrang, but they can definitely be encountered in the profiles of many late East Javanese monuments, such as candi Kidal, candi Kesiman Tengah, candi Jago, candi Kedaton and others.

For a moment I will return to the aforementioned typical Central Javanese tripartite profile combination, consisting of an ogive, a small tripartite moulding and a semi-circular moulding. It seems that candi Gunung Gangsir is the only East Javanese monument, after the shift of power from Central to East Java roundabout 900 A.D., which contains the true Central Javanese execution of this combination. Later in East Java, like at Belahan (cf. PI. 1) we encounter a similar tripartite combination, but the forms of both ogive and round moulding tend to differ. The shape of the slightly stretched "S" curve of the ogive becomes straighter, whereas the semi-circular moulding becomes slightly flatter and its outline becomes more pointed. Later again, like at candi Gurah (cf. PI. 1) this semi-circular moulding has in its entirety become flatter again and its outline has developed into a semi-oval moulding with a pointed end, whereas the ogive too has become flatter.

The next step is to be encountered at the East Javanese monument Candi Lor (Kab. Nganjuk), but also at the 11th century Balinese rock monuments at Gunung Kawi. The combination in its entirety is still present, but the semi-circular moulding has changed into a rectangular moulding with tapering end (cf. Pl. 1). The height of the ogive varies now and then, but the "S" shape tends to become more straight. The final step is to be met with at almost all late East javanese temples. Within the aforementioned combination the semicircular moulding has developed into a rectangular moulding, whereas the, in most instances, flat ogive now possesses an almost straight, slightly sagging contour (cf. PI. 1). Needless to say, this scheme of development is only tentative and some deviations certainly occur.

The second architectural element in this discussion is the profile of the series of mouldings which form the cornice above the die at the true teinple body (pls. 4,5). This element also contains details, 
characteristic of both Central and East Javanese temples. The successive order of mouldings is roughly similar to the one at Candi Loro Jonggrang: (f:om bottom to top) some projecting mouldings, a reset mouldin and some projecting mouldings again. On the other hand differenc:s exist between Candi Loro Jonggrang and Candi Gunung Gangsir. At Candi Loro Jonggrang few mouldings are ornamented; this is nc the case at Candi Gunung Gangsir. At Candi Loro Jonggrang he mouldings have a different height together with an irregular projection and recession of the mouldings. At Candi Gunung Gangsir the mouldings are of a different height too, but their projection and recession is regular. These features, not found at Prambanan, are, towever, common in late East Javanese temples, such as candi Kidal, the dated temple at Panataran and candi Kalicilik.

The third element is tile arrangement of the die of the base floors. This arrangement co isists of a horizontal distribution, which contains a series of decora ed panels. At both sides these panels are flanked by a series of slender, projecting and receding posts. Panels and slender post are llanked again on both sides by a broader post, of which the lower and upper parts are decorated. This arrangement is in many ways similar to the ones, encountered at some Central Javanese monuments, like candi Asu, candi Sojiwan and candi Loro Jonggrang.

As for the dies of the base floors of East Javanese monuments, it is only candi Sumbernanas, an early East Javanese monument, probably constructed in the first half of the 10th century and located some $15 \mathrm{kms}$. to the north of Blitar, which possesses an arrangement that shows rough similarities with the one, present at candi Gunung Gangsir.

The fourth architectural element is the arrangement of the wings of the staircase. The arrangement consists of three panels, surrounded and separated from each other by broad as well as slender projecting posts and mouldings. Once again similarities between candi Gunung Gangsir and candi Loro Jonggrang can be observed. There are, however, also differences. The main recessed panel in the wing of 
candi Loro Jonggrang is ornamented, whereas at candi Gunung Gangsir the wings are plain. Moreover, the Siwa temple of candi Loro Jonggrang possesses pseudo-monuments, fixed in the corner where the projection of the temple wall on one side meets the wing of the staircase on the other side. Candi Gunung Gangsir does not possess these pseudo-monuments. Concerning the East Javanese monuments, it is, once again, only candi Sumbernanas, which possesses a somewhat similar distribution of the wings of the staircase. On the other hand, the wings at candi Sumbernanas contain some decoration in the form of pendent volutes, which are not present at candi Gunung Gangsir. The wings of candi Gunung Gangsir show one element which we have not encountered in the wings of Central Javanese monuments. It is a low wide recessed panel underneath the main panel and separated from it by projecting mouldings. Most of the late East Javanese monuments, however, show a somewhat similar feature, although in a slightly changed form and arrangement. In this respect we mention candi Kesiman Tengah, candi Sawentar and the main temple at Panataran.

The last element which I would like to discuss is the series of niches against the true temple body of candi Gunung Gangsir. One niche consists of three elements (Pls. 7,8): a base, two niche pilasters and a roofing. The base interrupts the profile of the base mouldings of the true temple body; it is separately profiled (PI. 6) and made out of one piece. These features are also found at Central Javanese monuments, like candi Asu. A similar base is not present anymore at later dated East Javanese monuments.

At candi Gunung Gangsir each niche pilaster consists of three receding posts (Pls. 7,8,9). These posts are broadened at the base and at the top. This feature can partly be seen at Central Javanese monuments, especially the broadened part in the form of a makara at the base of the post which projects most (PI. 7). The particular profile at the base and the top of the hindmost post (Pls. 9,10:III) is a typical feature, present at candi Gunung Gangsir. The profile at the top of the hindmost post is, in a slightly more developed form, also present at some East Javanese monuments, like candi Kidal and candi Singosari. 
Another similarity with late East Javanese monuments is the roofing of the niche (PI. 8). It consists of a triangular crowning piece or tympanum on top of an architrave. This architrave consists of receding and projecting mouldings on both sides of it. A somewhat similar roofing can also be encountered at the 14th century candi Pari for example.

Considering the architectural evidence obtained from candi Gunung Gangsir it is possible to say that the monument possesses some architectural details which have not been found at Central Javanese monuments, but which can be observed at much later East Javanese temples. On the other hand, candi Gunung Gangsir contains many architectural features which point to late Central Javanese influence. In this Central Javanese context I might also add features like the ground-plan, the elevation, the eastern direction of the monument and the symmetrical arrangement of the floors (i.e. the left side of one temple side is a direct reflection of the right side).

In conclusion, it might be suggested that candi Gunung Gangsir is one of the first East Javanese monuments, built in a basically Central Javanese style, during or shortly after the shift of power from Central to East Java, sometime during the first three decennia of the tenth century A.D. On the other hand, it might be possible that candi Gunung Gangsir introduced into East Java some new architectural elements which have been adopted by much later East Javanese monuments. These new elements, however, are restricted to some details. These conclusion apply to the architecture of candi Gunung Gangsir. The doctoraal study by Klokke (1983), concerning the ornamental style of candi Gunung Gangsir led to similar conclusions.

\section{Conclusions}

Let us turn back to the opinions, which have been formulated earlier, concerning the possible relation between the Central and East Javanese art styles and the position of candi Gunung Gangsir within this relation. I can only agree with Brandes and Krom, considering 
the fact that they pointed at the Central Javanese style of the monument. On the other hand, because of the location of candi Gunung Gangsir in East Java and because of the applied building material, which is more frequently used in late East Javanese than in Central Javanese monuments, i.e. brick, they still considered the monument to be a link between the Central and East Javanese art styles. If we would still consider the monument to be a link in spite of its dominant Central Javanese style, we would do so because of the presence of a few late East Javanese elements and not merely because of the use of brick and because of its location in East Java. Brick has also been used in Central Java and in East Java some monuments are located which show a definitely early Central Javanese style, lika candi Songgoriti and candi Badut.

Although I formulated some objections against certain viewpoints of Pitono, I do agree with his suggestion that the early East Javanese period from the 10th until the 12th century (maybe even until the 11th century only) is a continuation of the Central Javanese period. This counts in particular for the architecture, like that of candi Gunung Gangsir. On the other hand, together with candi Gunung Gangsir, other East Javanese monuments dating from the period of the 10th and 11th centuries, like Belahan, Jolotundo, and Gurah, show new elements which point to the late East Javanese architecture. Because of this it is impossible to say that the architecture form the early East Javanese period (10th until 12th c.) in its entirety is a continuation of the architecture from the previous Central Javanese period. Only certain stylistic elements were continuously used during these two periods. Other features change but one is able to trace a development. Other characteristics disappear during the period under discussion and are, consequently, discontinuous, whereas new characteristics appear.

Considering the complex structure of the early East Javanese art and her relation to the Central Javanese art, and in view of the existing gap after the early East Javanese art, we might conclude that the picture with regard to the character of Old Javanese art and architecture is more complicated than the still existing idea, 
formulated thus: there exists either a gradual development (a certain continuity) or a contrast (a certain discontinuity) between the Central and East Javanese art forms. Only Bosch and, to a lesser degree, Galestin tried to break away from this somewhat rigid formulation.

For now it can only be concluded that more archaeological evidence from the period $1100-1250$ has to be brought forward in order to fill up the gap which exists within the art and architecture of the early East Javanese period. Besides this, an investigation into hopefully still existing, but not yet properly studied archaeological remains from the period $900-1250$ needs to be carried out. Together with this investigation a study of the mutual relation between these archaeological remains is necessary. This is why I have chosen this subject to be the focus of my doctoral research.

\section{BIBLIOGRAPHY}

Bosch. F.D.K. (\& B. de Haan) , 1965, The Old Javanese Bathing Place Jalatunda, BKI. CXXI, 189-233.

Brandes. J.L.A., 1903. Driemaandelijksch Rapport over April, Mei en Juni,

Brandes. J.L.A., 1903, Rapporten van de Commissie in NederlandschIndie voor Oudheidkundig Onderzoek op Java en Madoera. Batavia j's Graven hage.

Brandes. J.L.A., 1904, De Waarde van Tjandi Prambanan tegenover de andere Oudheden van Java, TBG , XLVIJ, 414- 432.

Dumacarvay. J., 1984, Gubahan Arsitektur Jawa Timur, Amerta (Berkala Arkeologi) 9, 7 - 13 . Jakarta.

Galestin, Th . P., 1936, Houtbouw op Oost - Javaansche Tempel reliefs. Dissertation Leiden. Den Haag, The Netherlands.

Hoffmanns, P.R., 1984, De Architectuur van Candi Gunung Gangsir. Deel I. II. Unpublished Doctoraal Thesis. Leiden, The Netherlands. 
Klokke, M.J., 1983, De Ornamentiek van Candi Gunung Gangsir. Unpublished Doctoraal Thesis. Leiden, The Netherlands.

Krom, N.J. 1923, Inleiding tot de Hindoe Javaansche Kunst, tweede herziene druk, Deel I, II. III. 's-Gravenhage, The Netherlands.

Pitono Hardjowardjojo, R., 1961 , Menindjau Tjandi Gunung Gangsir, Star Weekly, XVI. 808 , 28- 31, 47. Jakarta.

Pitono Hardjowardjojo, R., 1971, Notes on the Development of Temple Architecture in East Java. Journal of the Oriental Society of Australia , VIII, 1 \& 2. 68- 76.

Soekmono, R., 1969, Gurah. The Link between the Central and East Javanese Arts, Berita Pusat Penelitian Purbakala don Peninggalan Nasional. VI. Jakarta ,Indonesia.

Stutterheim, W.F., 1923, Oudjavaansche Kunst. BKI. LXXIX. 323 - 346.

Stutterheim, W.F., 1927, Oost Javaansche Kunst. Djawa. VII. 177 - 196. Java Instituut. Welteureden, Indonesia.

\section{ABBREVIATIONS}

BKI : Bijdragen tot de Taal-, Land. en Volkenkunde, uitgegeven door het Koninklijk Instituut voor Taal-. Land- en Volkenkunde. 's-Gravenhage. The Netherlands.

TBG : Tijdschrift voor Indische Taal., Land. en Volkenkunde, uitgegeven door het Bataviaasch Genootschap van Kunsten en Wetenschappen. Batavia, Indonesia. 


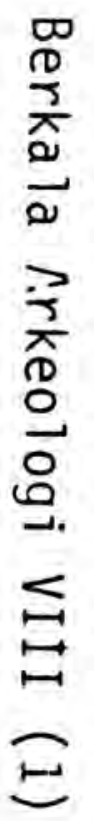

PL. 1 PROPOSED SCHEME OF DEVELOPMETT OF THE OGIVE AND THE SEYI-CIRCULAR MOULDING

\begin{tabular}{l|l|l|l|l|l|l} 
& $\begin{array}{l}\text { Late Central Javanese } \\
\text { monuments }\end{array}$ & Belahan & Candi Gurah & $\begin{array}{l}\text { Candi Lor } \\
\text { Candi Gunung Kawi }\end{array}$ & $\begin{array}{l}\text { Late East Jave- } \\
\text { nese moạments }\end{array}$ \\
\hline $\begin{array}{l}\text { ogive } \\
\text { semi- } \\
\text { moulding }\end{array}$ & & &
\end{tabular}


P1. 2 PROFILE,

FIRST BASE-FLOOR
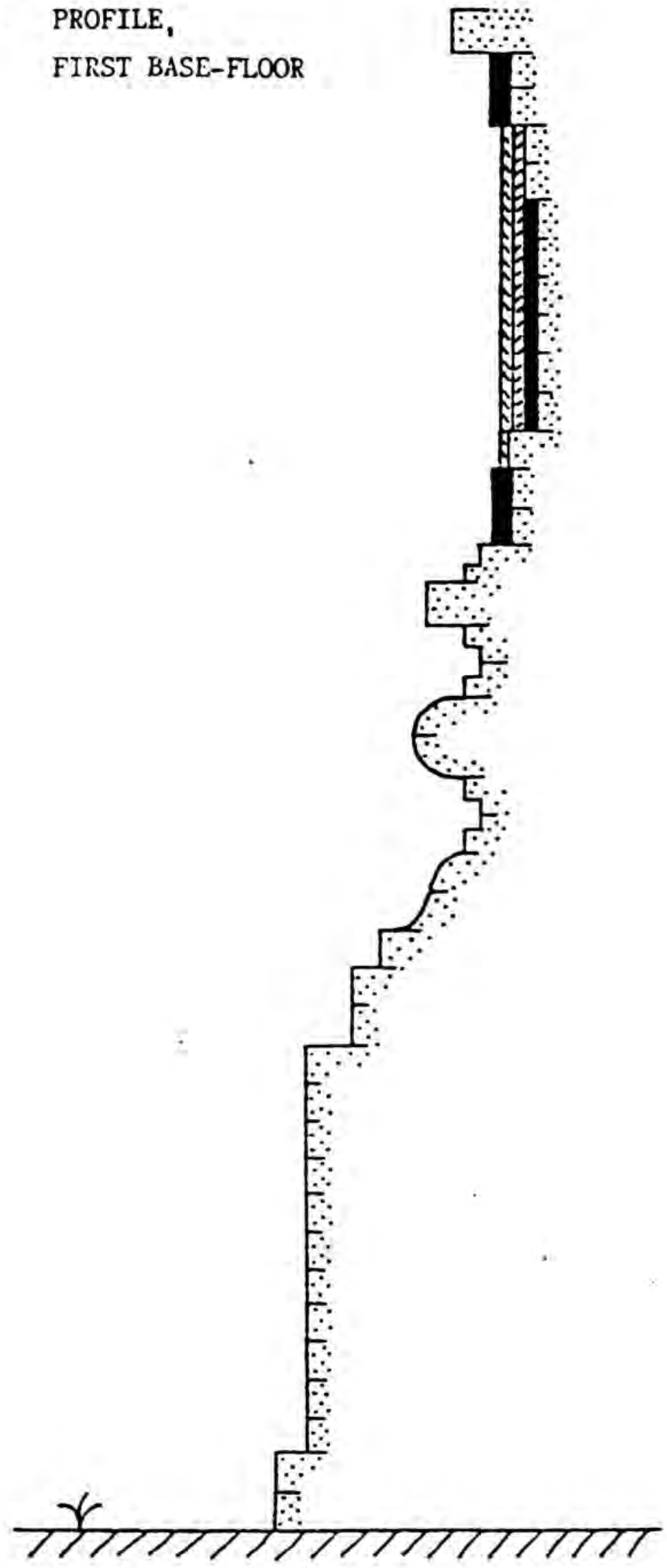
PL. 3 PROFILE,

SECONi BASE-FLONR

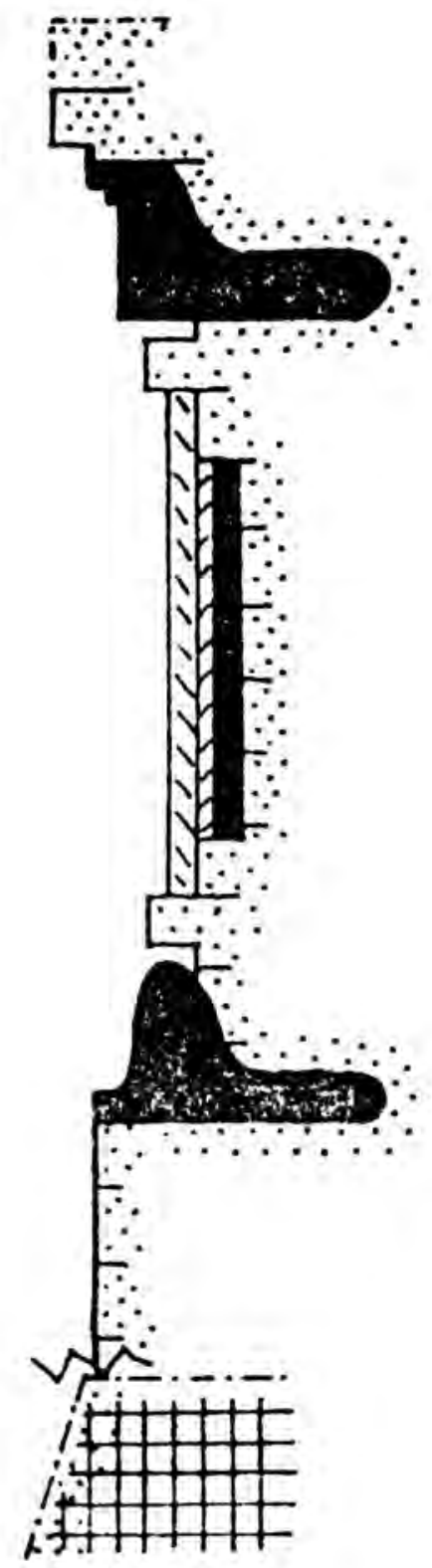

\section{_.... . DILAPIDATED \\ 目 CONSOLIDATED/RESTORED \\ 2. ORNAMENTED}




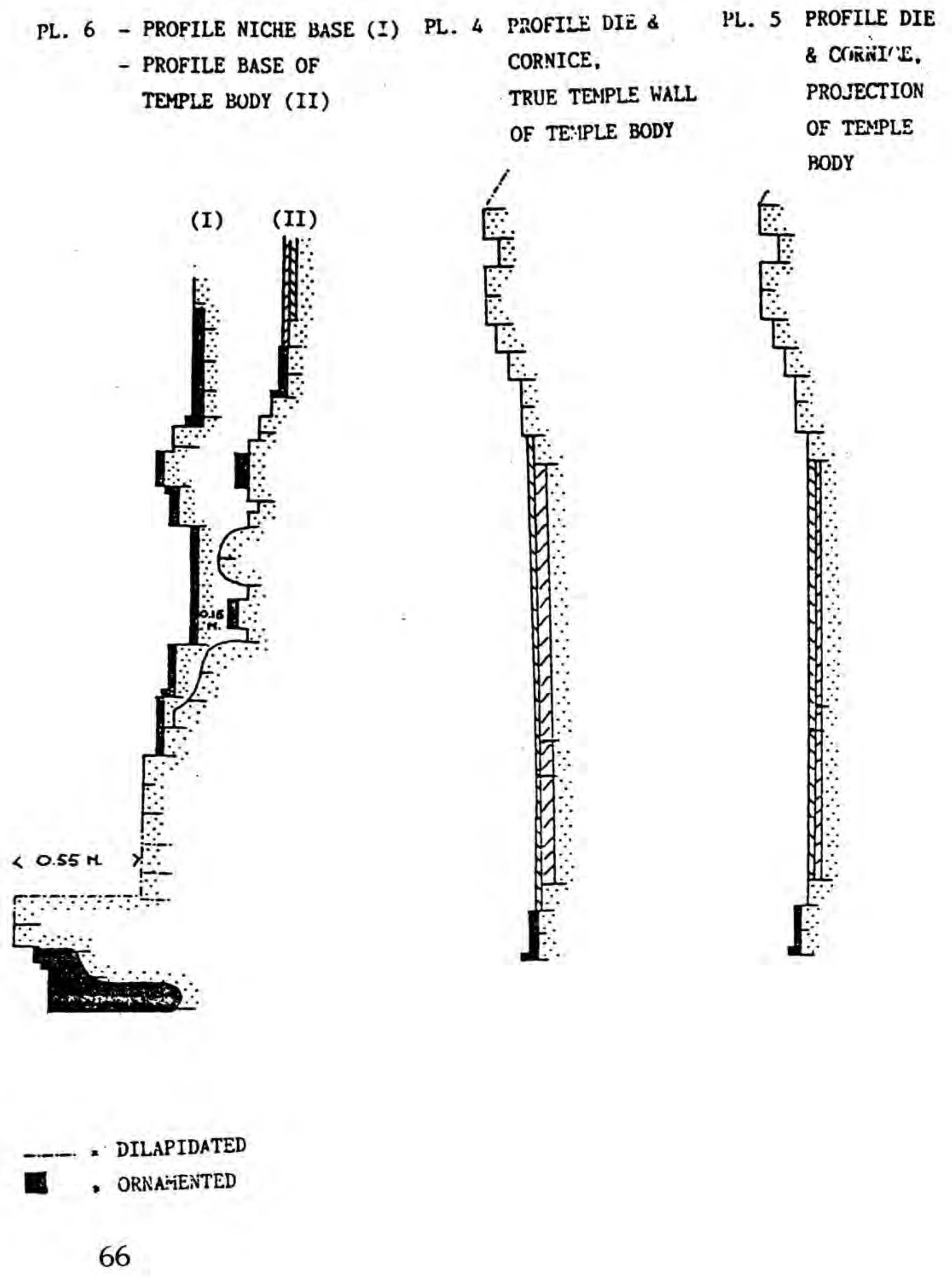


PL. 7 FRGiNT VIETi, BASE OF TENAPLE BODY. BASE OF NICHE, LOWER SECTION OF FICIL PILASTERS

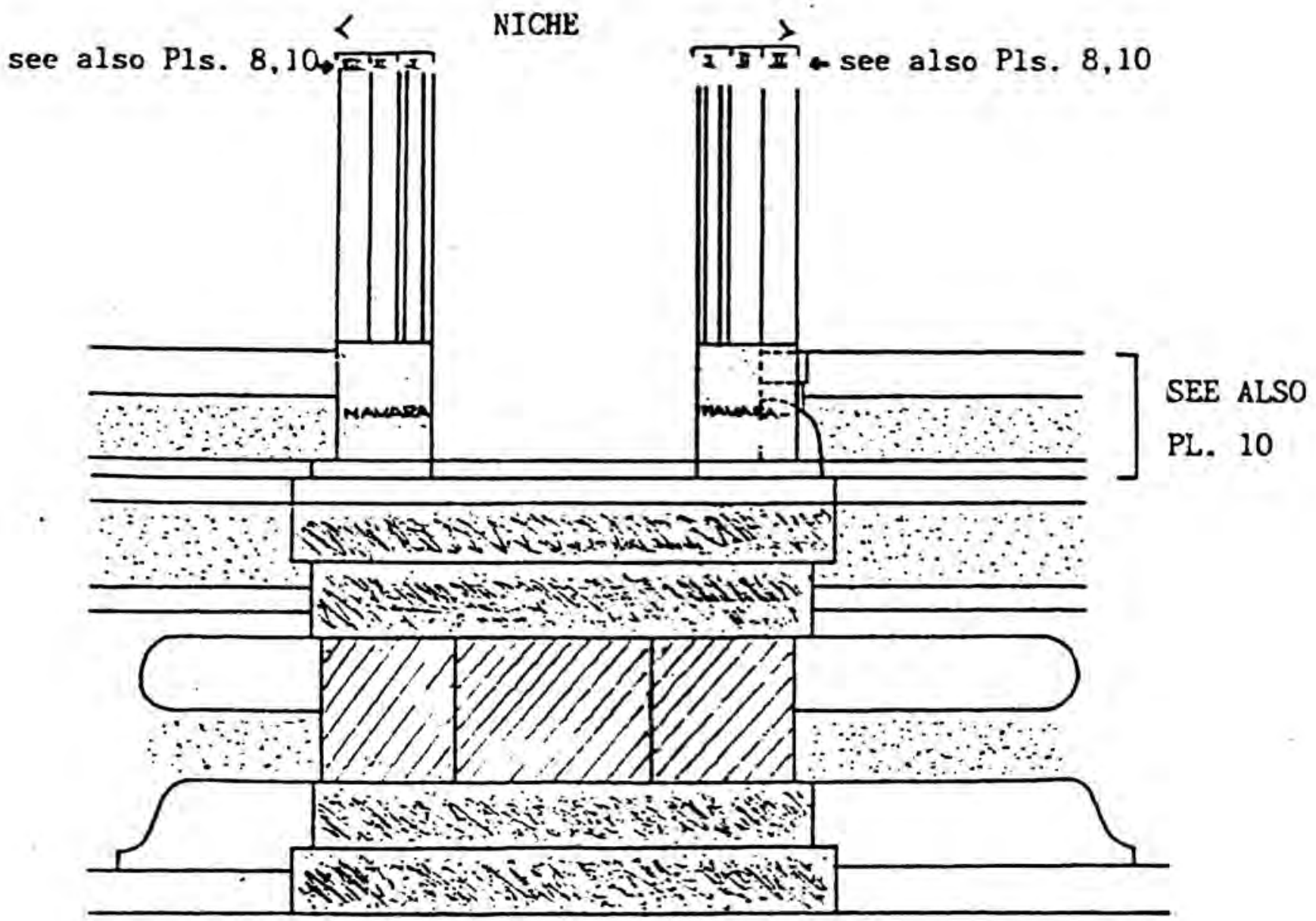

国 = ORNAMENTAL MOULDINGS, BASE OF TEMPLE BODY

图 = ORNAMENTAL MOULDINGS, BASE OF NICHE

ZZ = ORNAMENTAL PLAQUES, BASE OF NICIE 
PL. 8 TOP SECTION NICHE PILASTER \& CROWNING PIECE OF NICHE

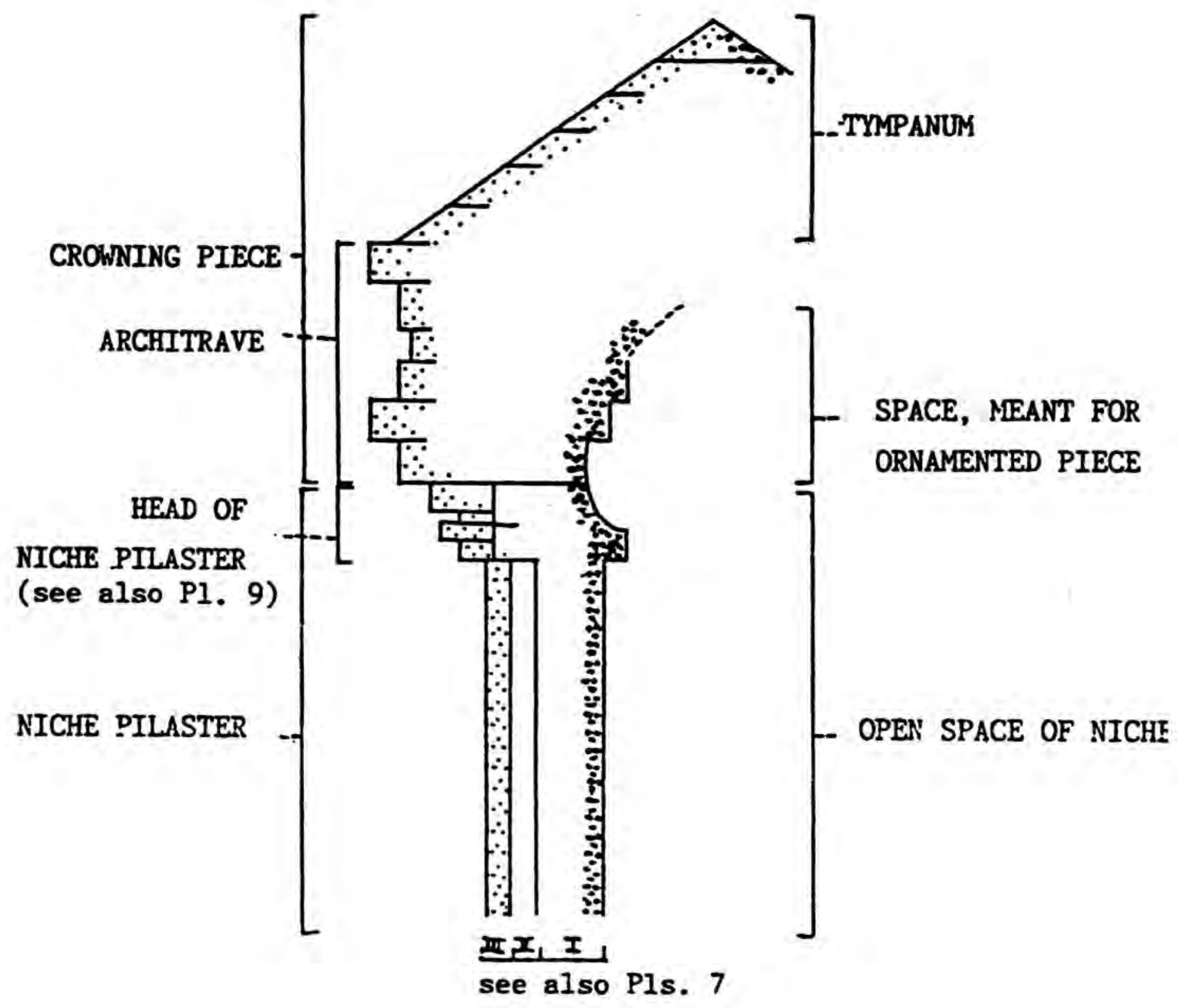


00
0
$\frac{0}{3}$
0
0
0
0
$\frac{1}{0}$
0
0
0
0
$\vdots$
$\Xi$
$\Xi$
$\Xi$

PL. 9 PROFILE, TOP SECTIONS OF THE

POSTS OF THE NICHE PILASTERS

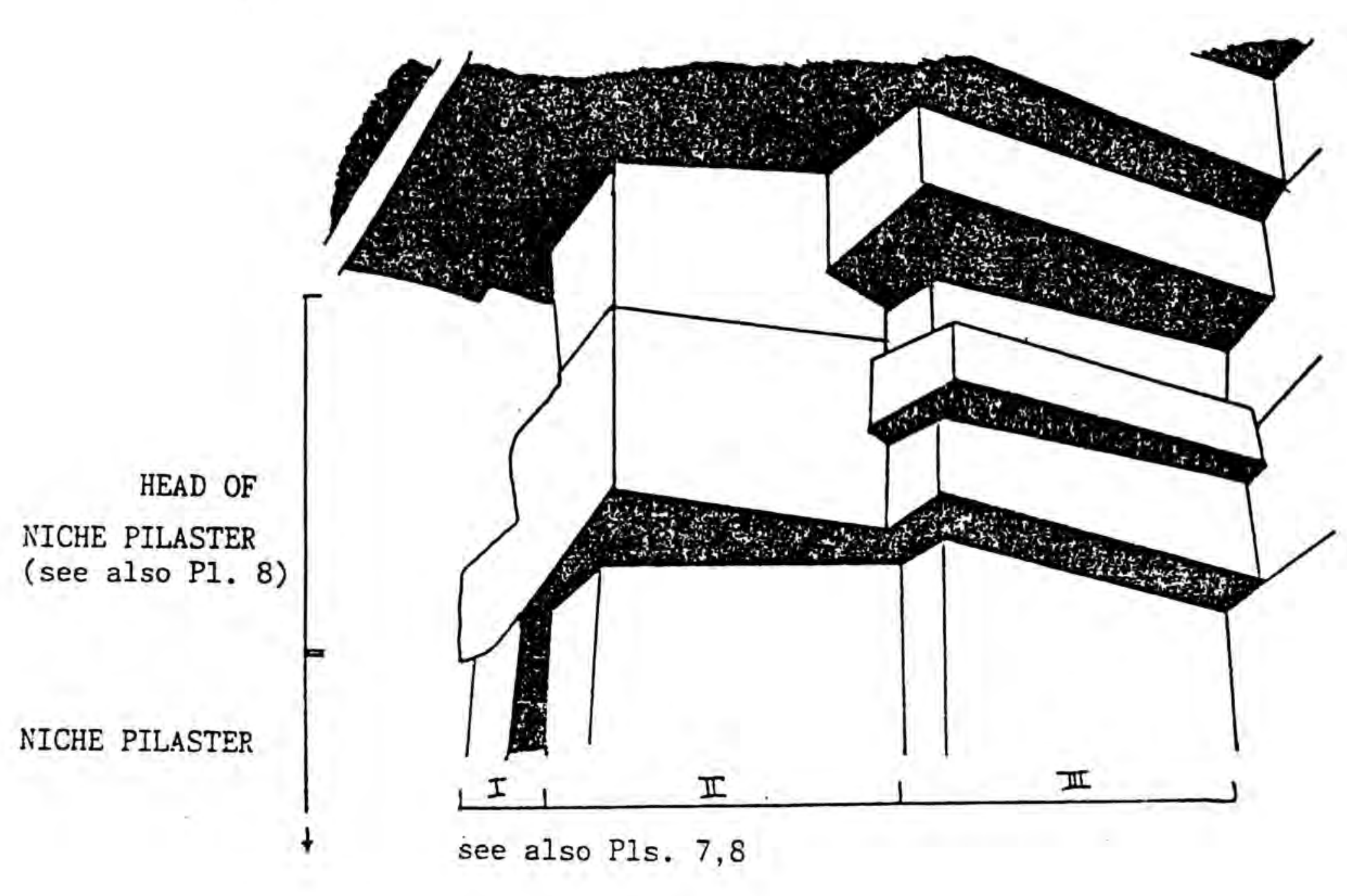

g) 
PL. 10 PROFILE, HINDMOST POST OF

NICHE PILASTER

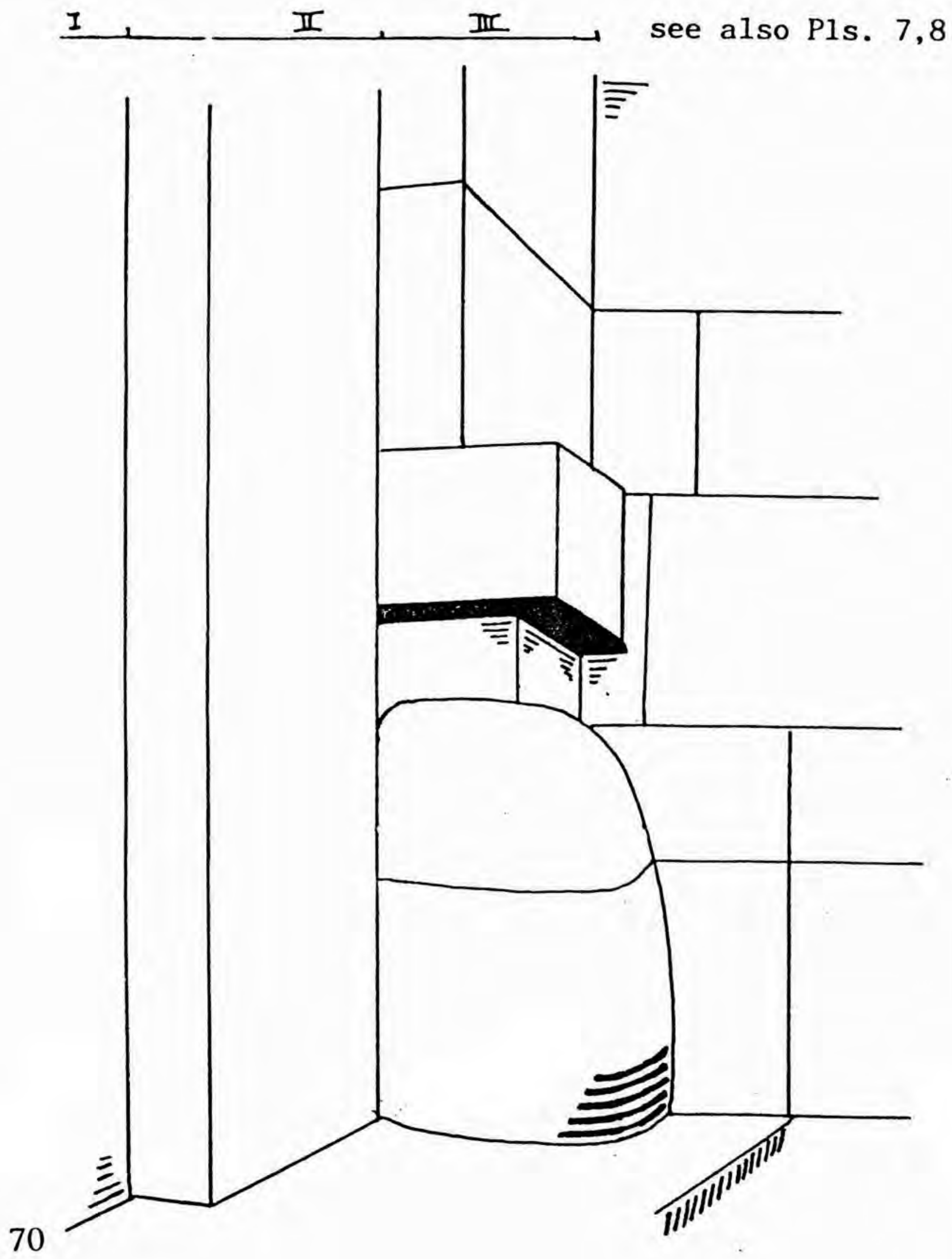

